\title{
Evangelical Dictionary of Theology
}

Treier, Daniel J. and Walter Elwell, eds. 2017. Evangelical Dictionary of Theology. Third Edition. Grand Rapids: Baker Academic. 976 pp. \$59.00. Hardcover.

Evangelicalism has changed since the publication of Baker's Dictionary of Theology more than sixty years ago. According to the World Christian Encyclopedia, there were 80 million evangelicals in the world in the year 1900, most of whom lived in the North-Atlantic West. By 2020, evangelicals numbered nearly 400 million (some estimates are significantly higher), the vast majority of whom are now diffused throughout Africa, Asia, and Latin America. As evangelicalism has expanded, a new generation of evangelical scholars has emerged. What Mark Noll called "the scandal of the evangelical mind" more than a quarter-century ago may now be coming to an end. Evangelicalism as a movement is now more diverse, and evangelical scholarship is more fertile. The editors of the third edition of the Evangelical Dictionary of Theology (EDT3) have responded to these changes by including more authors from "female, ethnic minority, and/or Majority World perspectives" in order to present "evangelical Christianity's fullness." They have also updated existing articles and bibliographies to reflect "recent scholarly developments" and "evangelical trends." Daniel Treier, professor of theology at Wheaton College (Wheaton, IL), has provided editorial leadership with the aim of producing a dictionary that is more reflective of global evangelicalism and better informed by fresh scholarship from an evangelical perspective.

EDT3 contains over 1,000 articles written by scholars covering a wide range of theological topics from A to Z-beginning with Abelard and ending with Zwingli. The work is updated throughout (including bibliographies) and slightly shorter than the first (1984) and second (2001) editions. The new edition eliminates material that is readily available in other publications while placing a greater emphasis on theology and theologians. The editors made the decision to omit full entries for living persons from this volume. Contemporaries who have shaped evangelical life and thought in the modern period-people like Billy Graham, Alister McGrath, Mark Noll, René Padilla, Pat Robertson, Andrew Walls, et al.-are mentioned within articles and bibliographies. Although full articles on modern-day figures may be missing, their influence on evangelical theology can still be felt.

The modern descendant of Baker's 1960 dictionary continues its legacy of presenting "the range of evangelical diversity accurately and the center of evangelical consensus winsomely." It offers an array of views on diverse topics, displaying what may be called broadminded evangelicalism. For example, the entry under "Atonement" shows that evangelicals hold differing perspectives on whether it is limited to the elect or unlimited for mankind. Under the article on "Baptism," a range of views are presented on both its meaning and mode in the evangelical tradition. The article on "Creation and Evolution" sets forth the varied opinions evangelicals hold on the subject of Genesis, origins, and science in irenic fashion. Feminism and the role of women in the church receives a balanced treatment, showing that evangelicals have not always agreed on these topics. The article on the World Council of Churches avoids fundamentalist polemics by providing a straightforward narrative of its history, only adding that evangelicals have sometimes "been critical of the WCC." The contributors have succeeded in "planting the evangelical flag in the middle of the road."

This new edition is chock-full of hearty entries that are popular among Protestant and evangelical Christians. These include subjects like the "Antichrist," "Augustine," "Biblical interpretation," "Conversion," "the Church Growth Movement," "Dispensationalism," "Fundamentalism," "Israel," 
"Imputation," "Jerusalem," “Justification," “Kenosis,” "Kerygma,” "Last Things,” the "Lausanne Covenant," "Millennialism," "Sanctification," and the "Rapture." Lengthy articles are included on "Evangelicalism," "Protestantism," and "Roman Catholicism." The dictionary also demonstrates that evangelical theology has been informed by the Great Tradition and the church catholic, revealed in its sympathetic treatment of topics like "Antony," "Anselm," the "Apostles' Creed," the "Apostolic Fathers," "Hans Urs von Balthasar," "Bernard of Clairvaux," "Celibacy," "Conciliarism," the "Dark Night of the Soul," "Ex Opere Operato," "Hyperdulia," "Images," "Mary,” the "Oxford Movement," "Saints," the "Society of Jesus," and the "Council of Trent." Laypersons and students will find readable and informative entries on topics like "Abortion," "Alcohol," the "Apocrypha," "Canon of Scripture," "Christian Liberty," "Christian Year (liturgical calendar)," the "Lord’s Day,” the "New Age Movement," the "Mark of the Beast," "Mormonism," "Pornography," the "Problem of Evil," "Pacifism," "Racism," "Relics," "Soul Sleep,” “C. S. Lewis,” the "Sovereignty of God," "Political Theology (politics),” and "Terrorism." Pastors and scholars will greatly appreciate the depth of scholarship in the articles and those looking for peer-reviewed articles and scholarly monographs will welcome the revised (and sometimes extensive) bibliographies under each entry.

Students who have turned their attention to theological developments in the non-Western world will be encouraged by fresh additions in EDT3. The entry "Global South Christianity" refers readers to generous overviews on "African Theology," "Asian Theology," "Chinese Theology," "Contextualization," and "Latin American Theology." The new dictionary may not fully satisfy evangelicals who are working in the cognate field of world Christianity. The well-written entry on "Evangelicalism" is largely a discussion of Western expressions of evangelicalism, with no reference to global developments. The entry under the Lausanne Covenant could have mentioned the way Latin American evangelicals effectively changed the way nearly all evangelicals now talk about evangelism and social responsibility. There is an article on Kwame Bediako, but non-Western evangelical theologians are largely unaccounted for. Some of these latter topics are covered in greater depth in the companion volume Evangelical Dictionary of World Missions (Baker 2000). While EDT3 may not present "evangelical Christianity's fullness," it does present a much fuller and richer treatment of what is now global evangelicalism. This remarkable volume is also the most current, scholarly, and readable dictionary for classic evangelical thought in the world today.

F. Lionel Young III

Research Associate

Cambridge Centre for Christianity Worldwide

Cambridge, England (UK) 